Pořízka J., Diviš P., Štursa V., Punčochářová L., Slavíková Z., Křikala J. 2021. Impact of organic and integrated pest management on the elemental composition of wine and grapes in a season with high fungal pressure. J. Elem., 26(4): 871-891. DOI: 10.5601/jelem.2021.26.3.2051

\title{
IMPACT OF ORGANIC AND INTEGRATED PEST MANAGEMENT ON THE ELEMENTAL COMPOSITION OF WINE AND GRAPES IN A SEASON WITH HIGH FUNGAL PRESSURE*
}

\author{
Jaromír Pořízka ${ }^{1,2}$, Pavel Divišs ${ }^{1,2}$, Václav Štursa ${ }^{1}$, \\ Lenka Punčochářová ${ }^{1}$, Zuzana Slavíková ${ }^{1}$, Jakub Křikala ${ }^{1}$ \\ ${ }^{1}$ Department of Food Chemistry and Biotechnology \\ ${ }^{2}$ Materials Research Centre \\ Brno University of Technology, Czech Republic
}

\begin{abstract}
The aim of this study was to compare organic and integrated pest management systems in terms of the influence of the application of specific pesticides on the elemental composition of grapes and wine. Samples of wine and grapes were obtained from an experimental vineyard estate running both viticulture systems. A comparison of agricultural techniques was carried out under identical climatic and soil conditions. Another important aspect of this study was the comparison in the 2019 season with high fungal disease pressure in the South Moravian Region, which forced the winegrower to use limited doses of protective agents, mainly based on $\mathrm{Cu}$. The work focuses on the determination of 15 elements (Na, Mg, Al, K, Ca, Cr, Mn, Fe, Co, Ni, $\mathrm{Cu}, \mathrm{Zn}, \mathrm{As}, \mathrm{Cd}, \mathrm{Pb}$ ) in soil, grapes and wine selected according to plant nutrition, toxicology and human diet. Elemental analysis of samples was carried out by inductively coupled plasma mass spectrometry (ICP-Q-MS). Differences in the elemental composition of samples from organic and IPM production were observed in all types of tested samples. The most fundamental differences were found in the case of $\mathrm{Cu}$. Due to the higher application dose of copper fungicides in organic vineyard, the concentration of copper in organic wine (Sauvignon blanc) was almost 3 times as high $\left(774 \pm 35 \mu \mathrm{g} \mathrm{l}^{-1}\right)$ as in wines from IPM $\left(259 \pm 27 \mu \mathrm{g} \mathrm{l}^{-1}\right)$. This study also demonstrated a direct effect of mancozeb application in IPM on elevated $\mathrm{Zn}$ an Mn levels in grapes and wine. However, none of the investigated elements exceeded the limits set by national, European or OIV regulations for wine.
\end{abstract}

Keywords: fungicides, pesticides, mancozeb, powdery mildew, copper.

Jaromír Pořízka, PhD, Department of Food Chemistry and Biotechnology, Faculty of Chemistry, Brno University of Technology, Purkyňova 118, 61200 Brno, Czech Republic, e-mail: porizka@ fch.vut.cz

* This work was financially supported by the project: Materials Research Centre at FCH BUT Sustainability and Development, REG LO1211, with financial support from the National Program for Sustainability I (Ministry of Education, Youth and Sports). 


\section{INTRODUCTION}

The demand for better wine has started a continuous process of improvements in viticulture, winemaking and wine storage, to satisfy the requirements of consumers and to obtain a maximal yield of optimal quality. The agriculture in the 1950s and 1960s emphasized the usage of mechanization, synthetic fertilizers and pesticides, which resulted in high yields of crops sold at a very low cost, but the price did not reflect issues of environmental damage. It creates concerns about long-term agricultural sustainability leading to the development of new sustainable agriculture (THomAs, Gunde 2014). Two main alternative viticulture systems, replacing conventional principles of winegrowing, were established in the countries registered in the International Organization of Vine and Wine (IOV) - Organic viticulture (OV) and the viticulture managed by the rules of Integrated pest management (IPM) - WiLLER, LERNOUd (2017).

The essential points of organic agriculture are described by the International Federation of Organic Agriculture Movement (IFOAM). Specifics about labelling and certification undergo to local legislation prescriptions. In the European Union it is Council Regulation (EC) No 834/2007 and No 889/2008. Organic agriculture in the USA is subjected to current regulations of the US Department of Agriculture (7 CFR Part 205 - National organic program). OfFERMAN and Nierberg in their overview from 2010 of the socio-economic performance of organic farming in Europe, estimated approximately $20 \%$ lower overall input costs of organic farms by lowering amounts of fertilizers, chemicals and energy, even when labor costs are much higher in comparison with conventional agriculture. It is also proven that organic food contains fewer contaminants (BAKER et al. 2002) and a higher level of secondary plant metabolites (Brandt, Mølgard 2001, Birzele et al. 2002). Organic farming focuses on minimizing damage to the environment by avoiding the usage of most mineral salt fertilizers and agrochemical pesticides. Application of beneficial insects, pheromones or manual weeding is used to reduce pests and disease. It also builds natural soil fertility by feeding soil instead of the plant (CARROLL 2016). If there is a real threat to a crop, only authorized plant protection products can be applied. All products or substances shall be of plant, animal, microbial or mineral origin. A list of protection substances is included in European regulation (EC) No 834/2007 Annex IIB. Copper and sulfur-based agents are approved to control major fungal diseases (FRAGOULIS et al. 2009).

Integrated pest management was developed to provide efficient pest and disease control by the integration of several control strategies to reduce reliance on pesticides. IPM in the Czech Republic represents a method of agricultural management with the main objective of ensuring sustainable development described by the law (CZ) No 17/1992 Annex 6. The practice of integrated pest management is based on pragmatic economical and sustainable 
philosophies. IPM uses targeted chemical crop protection if biological methods are not satisfactory or effective. Maximal application doses are set by the European Initiative for Sustainable Development in Agriculture (EISA) and by the regulations subjected to local initiatives of IPM, which provides supervision and grants permits for using an IPM label on products. The timing of the application of protective agents was greatly improved by the development of pest and disease outbreak prediction computer software, geographical information system and by the use of solar-powered weather stations. DARA (2021) defined IPM as a sustainable approach for managing pests by combining biological, cultural, and chemical tools in a way, that minimizes economic, environmental and health risks. It is an often-accepted view that yields of integrated farming are somewhere in the middle between standard yields of conventional agriculture and organic agriculture. It implies an idea, that IPM can be accepted as a third way for agriculture, which is sustainable both from an economic and environmental point of view.

Both agricultural systems emphasize different strategies of growing and protecting grapevine, which is reflected in the final quality and quantity of production. One of the most important quality standards that can be easily quantified is the elemental composition of grapes and wine. The elemental composition of grapes is influenced by viticulture practice, grapevine cultivar, environmental pollution, soil and climatic conditions (KABATA-PENDIAS 2010, PořízKA et al. 2018). Many research teams have confirmed a direct impact of viticulture practice on the elemental composition of wine and Vitis vinifera (GArcía-Esparza et al. 2006, LA Pera et al. 2008, VRČEK et al. 2011, KoreŇovskÁ, SuHAJ 2012, Martins et al. 2014, ČEPO et al. 2018).

Elemental analysis is a very useful tool for the determination of the nutritional value and safety of a product. Macro- and microelements in wines and grapes, such as $\mathrm{K}, \mathrm{Ca}, \mathrm{Cr}, \mathrm{Mg}, \mathrm{Fe}, \mathrm{Co}, \mathrm{Zn}$, Se, can play an important role in human nutrition. Conversely, $\mathrm{Ba}, \mathrm{As}, \mathrm{Cd}$ and $\mathrm{Pb}$ are potentially toxic in higher concentrations and must be closely monitored (MoNACI et al. 2003). The elemental composition is also linked to the overall organoleptic profile of wines. For example, higher concentrations of copper and iron can cause metallic and astringent taste and act as a catalyzer of oxidative reactions, which modify taste and may induce haziness (TARIBA 2011).

The aim of this study was to compare organic and integrated pest management systems in terms of the influence of the application of specific pesticides on the elemental composition of grapes and wine. Samples of wine and grapes were obtained from an experimental vineyard estate running both viticulture systems. An important aspect of this study was the comparison in the 2019 season with high fungal disease pressure in the south Moravian region, which forced the winegrower to use limited doses of protective agents. Determination of 15 elements (Na, Mg, Al, K, Ca, Cr, Mn, Fe, Co, Ni, $\mathrm{Cu}, \mathrm{Zn}, \mathrm{As}, \mathrm{Cd}, \mathrm{Pb}$ ) was performed. The selection of elements for this study was based on plant nutrition, toxicology and human diet. Elemental analysis of samples was carried out by inductively coupled plasma mass spectrometry 
(ICP-Q-MS) due to its high sensitivity and speed (STroH et al. 1994, NARDI et al. 2009). Experimental data were processed with analysis of variance (ANOVA) and principal components analysis (PCA).

\section{MATERIAL AND METHODS}

\section{Sampling site details and climatic data}

The vineyard estate Aeibis, which was selected for this study, is situated in the village of Ivan (Figure 1). This village belongs to the Mikulov wine sub-region of the Czech Republic and keeps both organic and integrated farming systems in the vineyards. Most of the vineyard area was converted from conventional viticulture to integrated pest management in 2006 . Approximately $20 \%$ of vineyards were adapted to an organic system. In 2009, the vineyards achieved certification according to regulations of the Ministry of Agriculture of the Czech Republic and Association of integrated and ecological production of grapes and wine (EKOVÍN integrated pest management organization). Organic and integrated sections were separated by $180 \mathrm{~m}$ (Figure 1).

Both experimental vineyards were planted with the Sauvignon variety, in 2004. The age of the experimental vineyards and rootstock (K5BB) was the same for organic and integrated pest management regions. Organic and

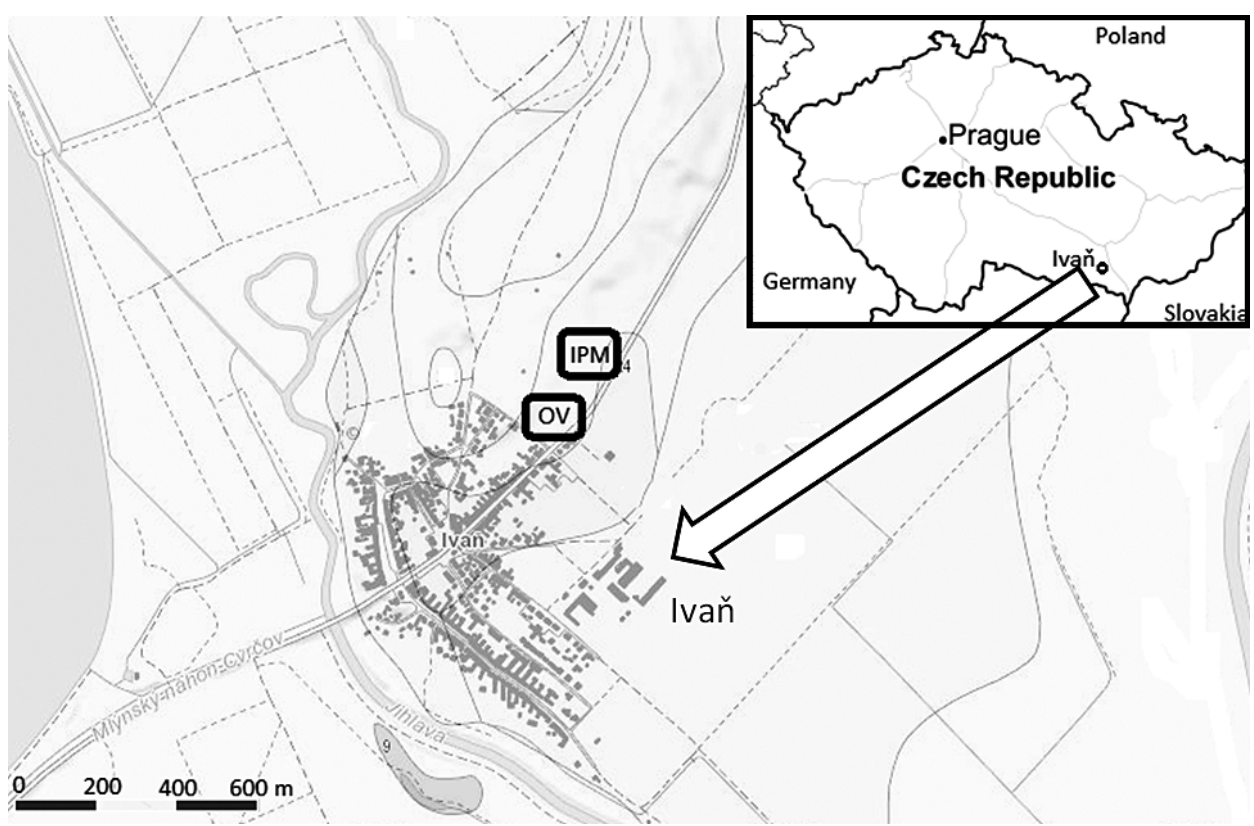

Fig. 1 Map of the location of the vineyards; OV - organic viticulture; IPM - integrated pest management 
IPM fields have identical soil and geological characteristics. A major proportion of soil was chernozem with a high contribution of humus and iron, and the bedrock was formed from loamy sediments. The average altitude of selected sampling blocks was $177 \mathrm{~m}$ above sea level. The long-term average of precipitation in the south Moravia region is $559 \mathrm{~mm}$ and the longterm average temperature is $8.9^{\circ} \mathrm{C}$. The wine production season of 2019 was characterised by mild winter, significantly higher precipitation $(728 \mathrm{~mm})$ and by higher average temp. $\left(9.5^{\circ} \mathrm{C}\right)$ in comparison with long term averages. Detailed climatic data are presented in the climate diagram (Figure 2).

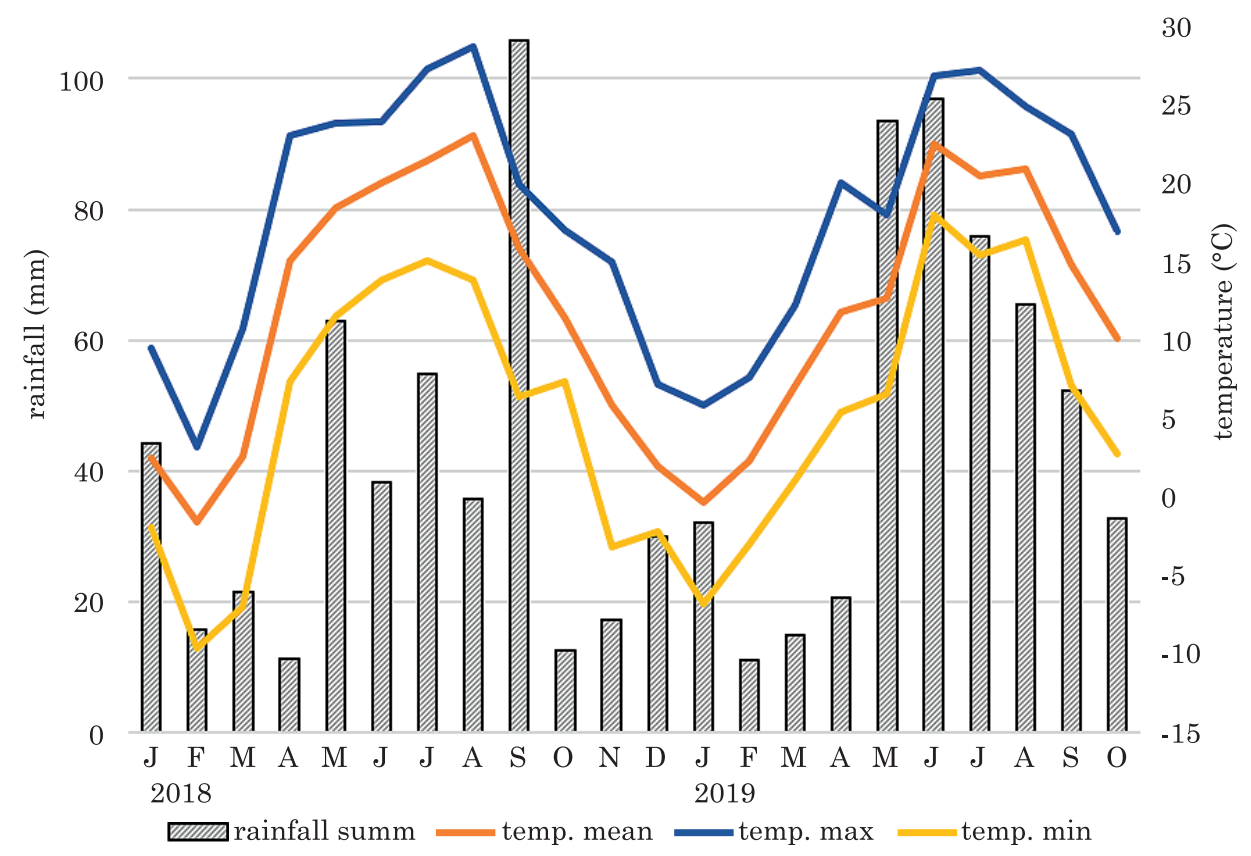

Fig. 2 Climate diagram of the tested area

The regional climate in 2019 was distinguished by warm and humid summer, resulting in the development of several fungal diseases. Potential Vitis vinifera infections were predicted by the weather evaluation software Galati-vitis (Galati, Slovakia). High threat by the pathogen Uncinula necator (powdery mildew) was determined from the beginning of June. The warning lasted until the middle of September. Another probable infectious pressure was predicted in the case of Plasmopara viticola (downy mildew) and Botrytis cinerea (grey mould) from the beginning of July until the harvest, and respectively the beginning of September until the harvest. Some of the south Moravia vineyards were infected by Metaspaeria diplodiella, and by Fomitiporia mediterranea. 


\section{Description of the methods of vine cultivation in experimental vineyards}

\section{Organic experimental vineyard}

Summary of protective agents used in the IPM vineyard with spraying period and dose is presented in Table 1 . The organic vineyard was treated

Table 1

List of the protective agents used on experimental vineyards

\begin{tabular}{|c|c|c|c|c|c|c|}
\hline $\begin{array}{r}\text { Speci- } \\
\text { fication }\end{array}$ & Agent & Activity & $\begin{array}{c}\text { Applica- } \\
\text { tions }\end{array}$ & $\mathrm{BBCH}$ & Dose per ha & $\begin{array}{c}\text { Week } \\
\text { of last } \\
\text { application }\end{array}$ \\
\hline OV & $\mathrm{Cu}(\mathrm{OH})_{2}$ & fungicide & 8 & 8 & $5.8 \mathrm{~kg}$ of $\mathrm{Cu}$ & $37^{\text {th }}$ \\
\hline OV & sulfur & fungicide & 5 & $55-81$ & $4 \mathrm{~kg}$ of $\mathrm{S}$ & $33^{\text {rd }}$ \\
\hline OV & $\mathrm{KHCO}_{3}$ & fungicide & 4 & $12-85$ & $3 \mathrm{~kg}$ & $37^{\text {th }}$ \\
\hline OV & potassium silicate & plant protection & 2 & $77-85$ & $2.5 \mathrm{~kg}$ & $29^{\text {th }}$ \\
\hline OV & algae extract & fungicide & 2 & $53-69$ & 41 & $27^{\text {th }}$ \\
\hline IPM & $\mathrm{Cu}(\mathrm{OH})_{2}$ & fungicide & 6 & 6 & $2 \mathrm{~kg}$ of $\mathrm{Cu}$ & $37^{\text {th }}$ \\
\hline IPM & $\begin{array}{l}\text { tebuconazole, } \\
\text { triadimenol, } \\
\text { spiroxamine }\end{array}$ & fungicide & 2 & $61-80$ & $75 \mathrm{~g} ; 50 \mathrm{~g} ; 13 \mathrm{~g}$ & $32^{\text {nd }}$ \\
\hline IPM & Folpet & fungicide & 6 & $53-80$ & $1 \mathrm{~kg}$ & $32^{\text {nd }}$ \\
\hline IPM & kresoxim-methyl & fungicide & 2 & $61-80$ & $0.2 \mathrm{~kg}$ & $32^{\text {nd }}$ \\
\hline IPM & Mancozeb & fungicide & 2 & $61-80$ & $1.625 \mathrm{~kg}$ & $32^{\text {nd }}$ \\
\hline
\end{tabular}

$\mathrm{OV}$ - organic viticulture, IPM - Integrated pest management

with a combination of copper and sulphur-based fungicides. Sulphur based agent Kumulus WG was applied at the first reported risk of grey mould development at $\mathrm{BBCH}$ stage 55 ( $23^{\text {rd }}$ week; inflorescence swelling). Sulphur agent was administered up to $\mathrm{BBCH} 79$ ( $30^{\text {th }}$ week; berry touch complete) in 5 doses in a total amount of $4 \mathrm{~kg}$ of sulphur per hectare. $\mathrm{Cu}(\mathrm{OH})_{2}$ solution was used as a primary protection agent against fungal diseases. It was applied from $\mathrm{BBCH} 55$ ( $23^{\text {rd }}$ week; inflorescence swelling) to $\mathrm{BBCH} 85$ ( $37^{\text {th }}$ week; softening of berries) in 8 doses in a total amount of $5.8 \mathrm{~kg}$ of $\mathrm{Cu}$ per hectare.

Potassium bicarbonate was used as fungicide against powdery mildew and grey mould. It was applied in 4 doses from $\mathrm{BBCH}$ stage $55\left(23^{\text {rd }}\right.$ week; inflorescence swelling) to 85 ( $37^{\text {th }}$ week; softening of berries) in a total amount of $3.5 \mathrm{~kg}$ per hectare. Sodium silicate was used for the fortification of the vine epidermis and increase of $\mathrm{pH}$ for better protection against powdery mildew and grey mould. It was applied at BBCH stage $77\left(29^{\text {th }}\right.$ week; begin of berry touch). Additionally, natural agents made from seaweed were used for the improvement of the immunity of vine. Organic vineyards were 
fertilized by the system subordinated to EC No. 834/2007 and No. 889/2008. Only organic fertilizers were used to manage optimal levels of $\mathrm{N}, \mathrm{P}, \mathrm{Mg}$, and $\mathrm{K}$ in soil. Fertilization was based on the addition of mulching straw and other kinds of green fertilizers. The system of cover crops planted between the rows was adopted. Prescribed mixtures of plants, which consisted of nitrogen-fixing plants, grass and richly flowering herbs, were used for the planting of cover crops. At least half of the species were deeply rooted plants. Pheromone evaporators were applied before the first raid of Lobesia botrana.

\section{Integrated pest management experimental vineyard}

The specification of the protective agents used in the IPM vineyard, including the spraying period and doses, is presented in Table 1 . The vineyards with the integrated pest management system were treated with the fungicide $\mathrm{Cu}(\mathrm{OH})_{2}$. The agent was sprayed in the same period as in the organic vineyard from $\mathrm{BBCH} 55$ ( $23^{\text {rd }}$ week; inflorescence swelling) to $\mathrm{BBCH} 85$ (37 th week; softening of berries) in 6 doses in a total amount of $2 \mathrm{~kg}$ of $\mathrm{Cu}$ per hectare. Other fungicides applied in the IPM vineyard were protective agents based on Mancozeb, Tebuconazole, Triadimenol, Sporoximine, Folpet, and Kresoxim-methyl. The IPM vineyards shared most of the fertilization methods with the organic system, including the management of cover crops. The main difference was the application of mineral nitrogen fertilizer (Agro CS, Czech Republic) in the IPM experimental vineyard. Fertilization was applied after the flowering (BBCH 69) at an amount of $40 \mathrm{~kg} \mathrm{~N} / \mathrm{ha}$ (Ekovín integrated pest management organization). The fertilizer consisted of nitrogen, phosphorus and potassium in a ratio of $12-6-18$, with $4 \%$ of magnesium. Pheromone evaporators were applied before the first raid of Lobesia botrana.

\section{Soil sampling and sample preparation}

Soil samples from both vineyards were collected. 12 sampling points were selected in each vineyard to obtain a representative sample. Samples were taken using a dedicated sampling device. A soil cylinder with the diameter of approximately $10 \mathrm{~cm}$ and the profile of $0-20 \mathrm{~cm}$ was taken from each sampling point. The samples were reduced by quaternation. Then, they were further ground in a ball mill. Microwave digestion was used for further sample preparation. Approximately $0.1 \mathrm{~g}$ of soil was weighed into PTFE vessels. $5 \mathrm{ml}$ of nitric acid (65\%, v/v, Analytica Praha, Czech Republic), $1 \mathrm{ml}$ of hydrogen peroxide (30\%, v/v, Analytica Praha, Czech Republic) and $2 \mathrm{ml}$ of hydrofluoric acid (40\%, v/v, Analytica Praha, Czech Republic) were added. Samples were digested using a microwave digestion system Milestone 1200 (Milestone Inc., Shelton, USA). Digested solutions were quantitatively transferred into $25 \mathrm{ml}$ volumetric flasks and diluted by purified water with resistivity $18.1 \mu \Omega . c m$ (ELGA, UK). A total of 12 samples from each viticulture were prepared for the experiments. 


\section{Grape sampling and sample preparation}

Grapes of the Sauvignon blanc cultivar of Vitis vinifera sampled at full ripeness from each viticulture system were chosen for comparison. The average sugar content of juice from grapes was $192.1 \pm 4 \mathrm{~g} \mathrm{~L}^{-1}$ in organic juice and $198.2 \pm 5.2 \mathrm{~g} \mathrm{~L}^{-1}$ in juice from the IPM production. Grapes from the IPM vineyards were harvested at the end of $40^{\text {th }}$ week and organic grapes were gathered at the beginning of $41^{\text {st }}$ week of 2019 . No rain was recorded in the period between harvest of OV and IPM grapes.

The systematic cluster sampling procedure from the bottom, middle and top part of the vine was used. Sample blocks of 100 vines in 5 rows were allocated for each viticulture system. Samples were gathered at the start, middle and end of the row. Three grape clusters were gathered from each vine, four samples in every row, hence the total number of samples was 60 clusters from each viticulture system. The samples were transported to the laboratory in plastic bags stored under dry ice. Ten grapes were further randomly selected from each cluster. Every sample was created by mixing of grapes from 3 clusters from one vine (total 30 fruits). Unwashed berries were purged from solid impurities and dried. After seed separation, berries were ground in liquid nitrogen into a powder. An amount of $300 \pm 5 \mathrm{mg}$ of such sample was weighed directly into PTFE vessels and $5 \mathrm{ml}$ of $\mathrm{HNO}_{3}\left(65 \%, \mathrm{v} / \mathrm{v}\right.$, Analytica Praha, Czech Republic) and $2 \mathrm{~mL}$ of $\mathrm{H}_{2} \mathrm{O}_{2}$ (30\%, v/v, Analytica Praha, Czech Republic) were added. Samples were digested using a microwave digestion system Milestone 1200 (Milestone Inc., Shelton, USA). Digested solutions were quantitatively transferred into $25 \mathrm{ml}$ volumetric flasks and diluted by purified water with resistivity $18.1 \mu \Omega . \mathrm{cm}$ (ELGA, UK). 20 samples from each viticulture were prepared for the experiments. All samples were digested in 2 independent replicates.

To compare wines, 2019 Sauvignon from organic and IPM production was prepared. The same oeno-practice was adopted for OV and IPM wines. Two batches of wine from each system were produced by the same technology and stored in stainless steel tanks. Wines were stabilized by $\mathrm{SO}_{2}$. Wine in five 0.7 wine bottles from each batch (in total 10 IPM and 10 organic) was collected and used for analysis.

Wine samples were prepared separately for elemental analysis and an analysis of total antioxidant activity. For the elemental analysis, wine samples were diluted in a 1:1 ratio with purified water. Dilution of the sample decreased ethanol concentration to the level which was sufficiently low to eliminate problems with matrix effects and plasma instability of ICP-MS.

\section{Elemental analysis of soil, grapes, and wine}

Multi-elemental analysis was carried out on a Thermo X-series inductively coupled plasma mass spectrometer (ICP-Q-MS) with a hexapole collision cell working in the $\mathrm{He} / \mathrm{H}$ mode (Thermo Fisher Scientific, Waltham, Massachusetts, USA). Both sample and skimmer cones were made from 
nickel. The instrument was equipped with an autosampler connected to a Micromist concentric nebulizer (Glass expansion, West Melbourne, Australia) with a Scott-type spray chamber for sample introduction. Experimental data were acquired by Plasma lab software (Thermo Fisher Scientific, Waltham, Massachusetts, USA).

Optimization of the ICP-Q-MS method was focused on maximizing sensitivity on desired masses while maintaining the oxide ratio for $\mathrm{CeO} / \mathrm{Ce}<0.01$. Typical sensitivity on ${ }^{115} \mathrm{In}$ mass was $>50000 \mathrm{cps}$ on $1 \mathrm{ppb}$ standard of In. The power of the radiofrequency generator was $1400 \mathrm{~W}$. Flow of collision gas and collision cell setting was tuned for assuring $<500 \mathrm{cps}$ on mass 80 to prevent interferences caused by polyatomic species formed in plasma. As internal standards, ${ }^{45} \mathrm{Sc},{ }^{115} \mathrm{In},{ }^{232} \mathrm{Th}$ (standards $1 \mathrm{~g} \mathrm{l}^{-1}$, Analytika Praha, Czech Republic) were used for matrix and drift corrections. The introduction of internal standards entailed the use of an internal standard kit (Thermo Fisher Scientific, Waltham, Massachusetts, USA). For the elimination of matrix effects, the calibration was prepared by the method of standard addition to wine. Calibration standards were prepared from $1 \mathrm{~g} \mathrm{~L}^{-1}$ stock standards (Astasol, Analytika Praha, Czech Republic). Data were acquired in the peak jump mode with $300 \mathrm{~ms}$ dwell time and 100 sweeps.

\section{Validation of ICP-MS methods}

ICP-MS methods were validated before the analysis. The limits of detection were calculated using the method of detection limit (MDL) at the confidence level 99\%. A mixed standard of all measured elements of a concentration $1 \mu \mathrm{g} \mathrm{l}^{-1}$ was measured 10 times. Detection limits were calculated. Detection limits are presented in result tables if a measured signal was below the detection limit.

Recovery of the methods were verified. Strawberry leaves were used as a replacement for official CRM for grapes (Metranal 3, Strawberry leaves, Analytika Praha, Czech Republic). Leaves were digested according to the identical procedure as grapes. Recoveries for all elements varied between $92 \%$ (Al) to $102 \%(\mathrm{Mn})$. Aluminious-sandy soil contaminated with heavy metals was used for recovery testing (AN-ZP02, Analytika Praha, Czech Republic). Soil was milled and digested according to the procedure used for real samples. Recovery rates varied from $89 \%$ (Al) to $10 \%(\mathrm{Fe})$. Recovery testing for wine was based on the measurement of a spiked Sauvignon sample. Wine was enriched with all tested elements from standards to a concentration of $50 \mu \mathrm{g} \mathrm{l}^{-1}$. Recovery rates varied from $95 \%$ (Al) to $99 \%$. The replicability of all methods was tested by the method of repeated measurements $(n=5)$ of selected samples of wine, grape, and soil digestates. Results were expressed in the form of RSDs\% and did not exceed 3\% for all elements.

Linearity of the method was verified by the evaluation calibration curves. Coefficient of determination $\left(r^{2}\right)$ was in all cases $>0.999$. 


\section{Statistical analysis}

Differences between the viticulture systems were evaluated by the $T$-test due to the normal distribution of data. Means of the concentration of elements were compared separately for grapes and wine of both viticulture systems. The level of significance was set at $95 \%$. Samples and links between observations and variables were also characterized by Principal component analysis (PCA) based on Pearson correlation. The statistical evaluation of experimental data was carried out in an Excel table processor (Microsoft, USA) and XL-stat (Addinsoft, France).

\section{RESULTS AND DISCUSSION}

\section{Analysis of soil in experimental vineyard}

For an objective evaluation of the influence of an agricultural technology on the elemental composition of wine, an elemental analysis of the soil in experimental vineyards had to be performed. Analysis of soil proceeded according to the method described in the materials and methods. Mean concentrations of elements and $T$-test comparison of production systems are presented in Table 2 .

Table 2

Summary of elemental analysis of soil

\begin{tabular}{|c|c|c|c|c|c|}
\hline \multirow{2}{*}{ Elements } & \multicolumn{2}{|c|}{ OV soil $\left(\mathrm{mg} \mathrm{kg}^{-1}\right)$} & \multicolumn{2}{c|}{ IPM soil $\left(\mathrm{mg} \mathrm{kg}^{-1}\right)$} & $T$-test \\
\cline { 2 - 6 } & $c$ & $\mathrm{SD}$ & $c$ & $\mathrm{SD}$ & $p$ \\
\hline $\mathbf{A s}$ & 1.9 & 1.8 & 1.3 & 0.6 & 0.3773 \\
\hline $\mathbf{B a}$ & 22.7 & 2.6 & 25.3 & 13.3 & 0.5785 \\
\hline $\mathbf{C a}$ & 59713 & 1843 & 56432 & 2641 & 0.3396 \\
\hline $\mathbf{C d}$ & 0.1 & 0.01 & 0.1 & 0.009 & 0.0518 \\
\hline $\mathbf{C o}$ & 2.2 & 0.1 & 1.9 & 0.3 & 0.0111 \\
\hline $\mathbf{C r}$ & 9.3 & 2.2 & 10.4 & 2.2 & 0.3104 \\
\hline $\mathbf{C u}$ & 14.2 & 0.4 & 9.6 & 0.6 & $<0.0001$ \\
\hline $\mathbf{F e}$ & 4326 & 592 & 4629 & 763 & 0.3599 \\
\hline $\mathbf{K}$ & 1023 & 95.3 & 982 & 57.3 & 0.2909 \\
\hline $\mathbf{M g}$ & 1050 & 71.1 & 1109 & 184.8 & 0.3804 \\
\hline $\mathbf{M n}$ & 193 & 22.8 & 175 & 19.5 & 0.0782 \\
\hline $\mathbf{N a}$ & 77.3 & 38.4 & 86.8 & 27.3 & 0.5572 \\
\hline $\mathbf{N i}$ & 10.2 & 4.8 & 8.1 & 2.2 & 0.2371 \\
\hline $\mathbf{P b}$ & 4.8 & 0.8 & 5.8 & 5.8 & 0.5997 \\
\hline $\mathbf{Z n}$ & 15.6 & 1.4 & 16.2 & 2.6 & 0.5735 \\
\hline
\end{tabular}


It is evident from the results of the $T$-test that the soil from both experimental vineyards does not significantly differ in elemental composition. Cobalt and copper are the only exception. Especially in the case of copper, there is a significant difference at $P<0.0001$. Soil from the field treated according to the principles of organic production showed the mean concentration of this element equal $14.2 \pm 0.4 \mathrm{mg} \mathrm{kg}^{-1}$. The IPM fields had lower mean content of $\mathrm{Cu}\left(9.6 \pm 0.6 \mathrm{mg} \mathrm{kg}^{-1}\right)$. This dissimilarity can be attributed to the different long-term application of copper fungicides in both viticulture. Organic production of grapes in comparison with integrated production allows the application of copper-based fungicides in higher quantities. The data show that since the division of the vineyard area in 2006 into organic and integrated section, there has been different accumulation of copper in the soil. However, the absolute amount of copper in the tested area is not high. The worldwide content of copper in soils varies from 1 to $140 \mathrm{mg} \mathrm{kg}^{-1}$ (MENGEL et al. 2001). Copper contamination in both vineyards is therefore low.

\section{Comparison of grapes from OV and IPM viticulture}

The results of the elemental analysis of grapes from both agriculture systems and $T$-test results are given in Table 3 .

Table 3

Summary of elemental analysis of grapes

\begin{tabular}{|c|c|c|c|c|c|}
\hline \multirow{2}{*}{ Elements } & \multicolumn{2}{|c|}{ OV Grapes $\left(\mu \mathrm{g} \mathrm{g}^{-1}\right)$} & \multicolumn{2}{c|}{ IPM Grapes $\left(\mu \mathrm{g} \mathrm{g}^{-1}\right)$} & $T$-test \\
\cline { 2 - 6 } & $c$ & $\mathrm{SD}$ & $c$ & $\mathrm{SD}$ & $p$ \\
\hline $\mathbf{A l}$ & 44.1 & 0.708 & 43.5 & 6.14 & 0.6986 \\
\hline $\mathbf{A s}$ & 0.016 & 0.001 & 0.179 & 0.025 & $<0.0001$ \\
\hline $\mathbf{B a}$ & 0.502 & 0.014 & 0.512 & 0.01 & 0.0215 \\
\hline $\mathbf{C a}$ & 108 & 5.1 & 112 & 5.17 & 0.0241 \\
\hline $\mathbf{C d}$ & $<\mathrm{LOD}$ & $<$ LOD & $<$ LOD & $<$ LOD & - \\
\hline $\mathbf{C o}$ & 0.002 & 0.0004 & 0.007 & 0.0002 & $<0.0001$ \\
\hline $\mathbf{C u}$ & 2.25 & 0.114 & 1.4 & 0.065 & $<0.0001$ \\
\hline $\mathbf{F e}$ & 12.5 & 0.294 & 11.7 & 4.38 & 0.4802 \\
\hline $\mathbf{K}$ & 1350 & 23.8 & 1271 & 44.7 & $<0.0001$ \\
\hline $\mathbf{M g}$ & 55.2 & 1.24 & 69.1 & 4.7 & $<0.0001$ \\
\hline $\mathbf{M n}$ & 2.88 & 0.056 & 3.67 & 0.311 & $<0.0001$ \\
\hline $\mathbf{N a}$ & 3.29 & 1.82 & 5.77 & 2.14 & 0.0005 \\
\hline $\mathbf{N i}$ & 0.012 & 0.003 & 0.013 & 0.001 & 0.6506 \\
\hline $\mathbf{P b}$ & $<\mathrm{LOD}$ & $<$ LOD & $<$ LOD & $<$ LOD & - \\
\hline $\mathbf{Z n}$ & 1.15 & 0.01 & 1.8 & 0.146 & $<0.0001$ \\
\hline
\end{tabular}

$\mathrm{OV}$ - organic viticulture, IPM - integrated pest management, * concentration in $\mathrm{mg} \mathrm{L}^{-1}$, $\mathrm{LOD}_{\mathrm{Cd}}-0.00008 \mu \mathrm{g} \mathrm{g}^{-1}, \mathrm{LOD}_{\mathrm{Pb}}-0.00016 \mu \mathrm{g} \mathrm{g}^{-1}$ 
Analyses have shown that organic grapes have a significantly different elemental composition from grapes from integrated production (Table 2). Organic grapes exhibited an overall higher concentration of $\mathrm{Cu}(P<0.0001)$. Organic grapes contained on average $2.25 \pm 0.114 \mu \mathrm{g} \mathrm{g}^{-1}$ of $\mathrm{Cu}$, while IPM grapes had $1.4 \pm 0.065 \mu \mathrm{g} \mathrm{g}^{-1}$ of $\mathrm{Cu}$. The fact that organic viticulture may result in higher residues of copper in grapes is probably caused by the permission to apply higher doses of copper-based pesticides (compared to IPM) in organic farming. This was reflected in a higher concentration of copper in the soil of OV section in comparison with IPM section. However, the difference in absolute values was not so large, and both vineyards were characterized by a low absolute copper content in soil. Thus, a more logical explanation for the differences can be found in the application of copper fungicides directly to the plant rather than to the contribution of root accumulation. At the time and place of the study, farmers were able to spray copper salts solutions in an amount of $30 \mathrm{~kg} \mathrm{ha}{ }^{-1}$ of $\mathrm{Cu}$ during a 5-year period with the smoothing mechanism. The local limit in the experimental vineyard, based on the evaluation of the previous application of copper pesticides, was set at $6 \mathrm{~kg} \mathrm{ha}^{-1}$ of $\mathrm{Cu}$ in 2019. Application of copper in the IPM vineyard was limited to only $2 \mathrm{~kg} \mathrm{ha}^{-1}$ per year according to the EKOVIN association rules. Due to the climatic conditions and high fungal diseases pressure, limited doses of copper-based pesticides were reached both in organic $\left(5.8 \mathrm{~kg} \mathrm{ha}^{-1}\right.$ of $\mathrm{Cu})$ and IPM $\left(2 \mathrm{~kg} \mathrm{ha}^{-1}\right.$ of $\left.\mathrm{Cu}\right)$ parts of tested vineyards. The impact of the application dose of copper-based pesticides on the residual concentration of $\mathrm{Cu}$ in Vitis vinifera was substantially studied by several authors. Similar conclusions concerning the effect of fungicide application on the concentration of copper in wine and grapes were published by LA PERA et al. (2008). Grapes treated with copper oxychloride showed a significant increase of $\mathrm{Cu}$ in comparison with control and with samples treated with zoxamide-mancozeb mixture. The copper amount increased by $50 \%$ compared to control or zoxamide-mancozeb samples, which is comparable with the presented results. MARTins et al. (2014) studied the impact of Bordeaux mixture application $\left(\mathrm{CuSO}_{4}+\mathrm{Ca}(\mathrm{OH})_{2}\right)$ on copper levels in grapes. The application dose and number of applications were based on the regular vineyard management of commercial organic farms. Grapes treated by Bordeaux mixture showed 7-14 times higher concentration of copper than control untreated fruits. GARCIA-EsParza et al. (2006) found a positive correlation between the copper residue concentration in grapes and the total amount of copper applied in vineyards. A direct effect of the method of treating the vine on the copper content of the grapes has therefore been demonstrated.

Another notable difference in the elemental composition of tested grapes was observed in the concentration of zinc $(P<0.0001)$ and manganese $(P<0.0001)$. Significantly higher concentrations of those elements were observed in IPM samples, and it is probably associated with the application of Ridomil GOLD MZ 68 WP, which is a fungicide based on dithiocarbamate mancozeb $\left[\mathrm{C}_{4} \mathrm{H}_{6} \mathrm{~N}_{2} \mathrm{~S}_{4} \mathrm{Mn}\right] \mathrm{x}(\mathrm{Zn}) \mathrm{y}$, containing zinc and manganese in an orga- 
nic complex form. The application of this group of pesticides is strictly prohibited in organic viticulture. The observed differences in the content of zinc and manganese are in agreement with the research conducted by LA PERA et al. (2008), aimed at the evaluation of the influence of the fungicide mancozeb on the elemental composition of Italian red wines and grapes. Samples from vineyards treated with mancozeb showed notably higher concentrations of zinc and manganese in grapes than in the control samples. The magnitude of the difference was also influenced by the time difference of the last mancozeb application and harvest. Later application resulted in higher amounts of zinc in wine.

Concerning macro-elements, the most significant difference between the grapes $(P<0.0001)$ from OV and IPM production were found in the concentration of potassium. Detail analysis of the plant protection and fertilizing procedures in both OV and IPM systems may suggest a potentially higher concentration of potassium in IPM samples owing to the additional NPK fertilization. The results of this study revealed the exact opposite. Grapes and wine from OV contained higher amounts of potassium than in the IPM counterparts (Table 2). There are several possible explanations, or a combination thereof. Grapes from the organic vineyard were additionally treated with $\mathrm{KHCO}_{3}$. The solution was sprayed four times from $23^{\text {rd }}$ to $37^{\text {th }}$ week of 2019, at a dose of $3 \mathrm{~kg}$ per hectare. The substance protects the plant against fungal diseases by changing $\mathrm{pH}$ of the surface layer of grapes. Organic vines were also treated with potassium water glass, providing two sprays at $\mathrm{BBCH} 77$ and 85 and a total dose of $2.5 \mathrm{~kg}$ per hectare. The last application of water glass was performed in $37^{\text {th }}$ week of 2019. If these direct effects are discarded, there can be also a biochemical explanation of this phenomenon. Potassium deficiency in most crop species can decrease plant immunity against pathogens (WhITELAW-WECKERT et al. 2011). Potassium ions support the development of a strong cell wall of grapes, and are also important in the biosynthesis of phenolic compounds, which are important for additional self-protection (WANG et al. 2013). Potassium also plays an important role in the regulation of stomatal closure. Stomata and lenticels are crucial points for infection attacks and proper metabolic reactions can prevent grape diseases (WhitelaW-WECKeRT et al. 2011). Organic viticulture, with its strategy of minimizing pesticide application, relies more on plant self-protection mechanism. Vine is stressed more by fungal infections without the application of synthetic, selective, and highly effective fungicides. This stress may induce the onset of different plant self-protecting mechanisms related to potassium metabolism and may be a cause of the element's higher concentration in grapes.

The analyzed grapes also contained trace amounts of arsenic. It was proven that the tested organic grapes $\left(0.016 \pm 0.001 \mu \mathrm{g} \mathrm{g} \mathrm{g}^{-1}\right)$ exhibited significantly $(P<0,0001)$ lower amounts of arsenic than IPM grapes $\left(0.179 \pm 0.025 \mu \mathrm{g} \mathrm{g}^{-1}\right)$. It can be explained by the release of As from the sub-soil by the reduction of iron hydroxides and subsequentially desorption of As when ammonium 
nitrogen is present, which is linked to the application of mineral NPK fertilization in the IPM viticulture.

Multivariate characterization of grape samples was performed by PCA. Factor loadings and biplot projections of observations on 2D graph of principal components are presented in Table 4 and Figure 3. The first two compo-

Table 4

Principal component analysis factor loadings of grape samples

\begin{tabular}{|c|c|c|c|}
\hline Wine & F1 & F2 & F3 \\
\hline $\mathrm{Na}$ & -0.0481 & 0.7584 & -0.0044 \\
\hline $\mathrm{Mg}$ & 0.0586 & 0.5244 & -0.3893 \\
\hline $\mathrm{K}$ & 0.6106 & 0.1157 & -0.3579 \\
\hline $\mathrm{Ca}$ & -0.3963 & -0.3924 & 0.0078 \\
\hline $\mathrm{Mn}$ & -0.8493 & 0.0159 & -0.0829 \\
\hline $\mathrm{Al}$ & -0.2247 & -0.064 & 0.6962 \\
\hline $\mathrm{Fe}$ & 0.6578 & 0.3166 & 0.3999 \\
\hline $\mathrm{Co}$ & -0.2527 & 0.655 & 0.5631 \\
\hline $\mathrm{Ni}$ & -0.8037 & 0.0231 & 0.2608 \\
\hline $\mathrm{Cu}$ & 0.9634 & -0.0287 & 0.0821 \\
\hline $\mathrm{Zn}$ & -0.9491 & 0.0444 & -0.1003 \\
\hline $\mathrm{As}$ & -0.3561 & 0.4532 & -0.114 \\
\hline $\mathrm{Ba}$ & -0.2422 & -0.288 & 0.0766 \\
\hline $\mathrm{Pb}$ & -0.2704 & 0.0671 & -0.1323 \\
\hline $\mathrm{Sr}$ & 0.3285 & -0.2007 & 0.5693 \\
\hline
\end{tabular}

nents for grape samples PCA (from a total of 13 components) comprised $63.51 \%$ of total variability with similar factor loadings as in the case of wine PCA. Beside Mn and Zn, magnesium proved to be influential for the separation of observations into groups. The higher concentration of $\mathrm{Mg}$ in IPM grape samples is probably due to the application of mineral NPK fertilizer which was enriched with $4 \%$ of magnesium. Clear separation of groups was also possible thanks to significant differences in the arsenic content. All these mentioned parameters had factor loadings for component F1 higher than 0.8.

\section{Comparison of wine from OV and IPM viticulture}

Differences in the elemental composition of grapes were in many cases also reflected in the wine made from these grapes. Mean concentrations and $T$-test results are presented in Table 5.

The most significant difference $(P<0.0001)$ was again observed in the content of copper. The mean concentration of $\mathrm{Cu}$ was higher in samples of wine from organic viticulture system $-774 \pm 35 \mu \mathrm{g} \mathrm{l^{-1 }}$, which was almost three times 


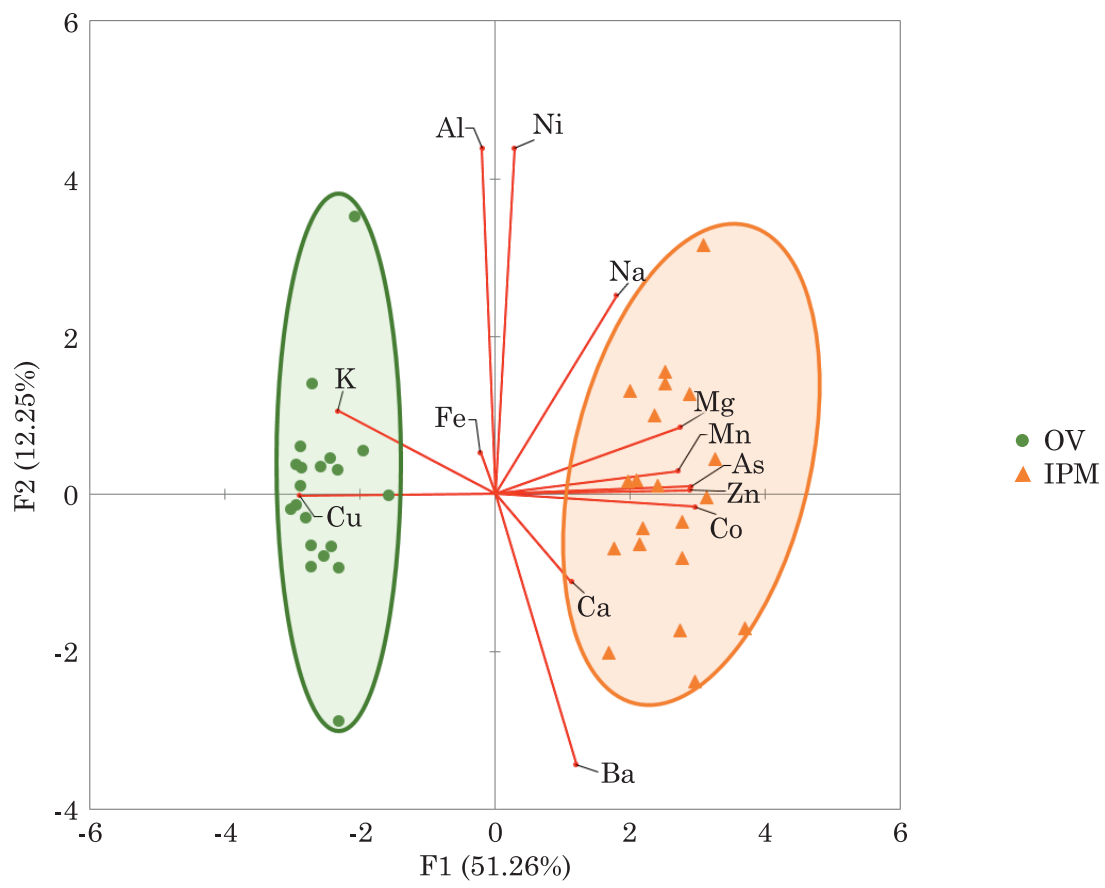

Fig. 3. PCA biplot of grape samples (ellipses are only for the visual purpose): $\mathrm{OV}$ - organic viticulture, IPM - integrated pest management

more than in tested Sauvignon wines from the IPM production $\left(259 \pm 27 \mu \mathrm{g} \mathrm{l}^{-1}\right)$. The copper residue in organic wine was close to the $1 \mathrm{mg} \cdot \mathrm{l}^{-1}$ limit set in the current Czech legislation and in the OIV recommendation. The copper content in wines must be closely monitored both for the effects on qualitative properties of the product and for the consumer health protection. Elevated copper levels in wine can be harmful to liver metabolism, they can promote formation of free radicals and can also affect the central nervous system (ARAYA et al. 2007). A concentration of copper $>0.5 \mathrm{mg} \mathrm{l}^{-1}$ in white wine might be problematic due to the possible formation of cupric and cuprous sulphides in the absence of oxygen and presence of sulphur dioxide $(12,13$ Harald Claus). Therefore, with stronger sulphurisation, this phenomenon could occur in wines from organic production.

General assessment of the effect of the different production systems on the copper content of wine was studied by several authors. VRČEK et al. (2011) observed a higher concentration of copper in Croatian organic wines, compared to conventional production. Copper residues were still under the limit of $1 \mathrm{mg} \mathrm{l}^{-1}$. In their general evaluation of Italian wines from conventional, integrated and organic production, GARCIA-EsparZA et al. (2006), did not find any significant differences in concentrations of copper. It should be noted that variability within individual groups was high. KoŘEŇOvSKÁ and SUHAJ (2012) found a higher concentration of copper in Slovakian conventional 
Summary of elemental analysis of wine

\begin{tabular}{|c|c|c|c|c|c|}
\hline \multirow{2}{*}{ Elements } & \multicolumn{2}{|c|}{ OV wine $\left(\mu \mathrm{g}^{\mathrm{l}^{-1}}\right)$} & \multicolumn{2}{c|}{ IPM wine $\left(\mu \mathrm{g} \mathrm{l}^{-1}\right)$} & $T$-test \\
\cline { 2 - 6 } & $c$ & $\mathrm{SD}$ & $c$ & $\mathrm{SD}$ & $p$ \\
\hline $\mathbf{A l}$ & 281 & 10.2 & 281 & 5.1 & 0.9233 \\
\hline $\mathbf{A s}$ & 1.93 & 0.99 & 2.41 & 0.484 & 0.2175 \\
\hline $\mathbf{B a}$ & 22.22 & 0.66 & 22.53 & 0.36 & 0.6582 \\
\hline $\mathbf{C a}$ & $84.7^{*}$ & $5^{*}$ & $90.4^{*}$ & $14.6^{*}$ & 0.3026 \\
\hline $\mathbf{C d}$ & $<\mathrm{LOD}$ & $<\mathrm{LOD}$ & $<\mathrm{LOD}$ & $<$ LOD & - \\
\hline $\mathbf{C o}$ & 0.869 & 0.034 & 0.892 & 0.044 & 0.259 \\
\hline $\mathbf{C u}$ & 774 & 35 & 259 & 26.9 & $<0.0001$ \\
\hline $\mathbf{F e}$ & 325 & 4.67 & 311 & 10.9 & 0.0031 \\
\hline $\mathbf{K}$ & $698^{*}$ & $62.3^{*}$ & $625^{*}$ & 33.7 & 0.0091 \\
\hline $\mathbf{M g}$ & $73.47^{*}$ & $2.74^{*}$ & $73.43^{*}$ & 2.3 & 0.9744 \\
\hline $\mathbf{M n}$ & 311 & 23.5 & 390 & 23.3 & $<0.0001$ \\
\hline $\mathbf{N a}$ & $7.97^{*}$ & $0.37^{*}$ & $8.01^{*}$ & $0.38^{*}$ & 0.9241 \\
\hline $\mathbf{N i}$ & 19.1 & 1.36 & 21.97 & 1.3 & 0.0021 \\
\hline $\mathbf{P b}$ & 0.9 & 0.03 & 0.91 & 0.022 & 0.9499 \\
\hline $\mathbf{Z n}$ & 407 & 4.06 & 565 & 17.8 & $<0.0001$ \\
\hline
\end{tabular}

$\mathrm{OV}$ - organic viticulture, IPM - integrated pest management, * concentration in $\mathrm{mg} \mathrm{L}^{-1}$, $\mathrm{LOD}_{\mathrm{Cd}}-0.001 \mu \mathrm{g} \mathrm{l}^{-1}, \mathrm{LOD}_{\mathrm{Pb}}-0.002 \mu \mathrm{g} \mathrm{l}^{-1}$

wines in comparison to organic production, both for red and white samples. ČEPO et al. (2018) presented a comparison of conventional and organic wines from different locations of Croatia. In terms of a copper concentration, data were highly inconsistent with no significant trend to assign. A comprehensive review of these studies demonstrates that a residual concentration of copper in wine is strongly connected to specific treatments within the production systems and can be highly variable. It is difficult to draw a general conclusion indicating copper contamination as attributed to an individual viticulture system from a long-term perspective, and this parameter is highly dependent on climatic and pest conditions of a specific seasons. However, it can be stated that the application of limited doses of copper pesticides can result in an increased copper concentration in wine and grapes.

Higher concentrations of zinc and manganese in IPM grapes were reflected in IPM Sauvignon wine $(P<0.0001)$. The explanation of this finding as induced due to the application of mancozeb is described above. Wines usually contain 0.2 to $0.5 \mathrm{mg} \mathrm{l}^{-1}$ of zinc and 0.3 to $0.4 \mathrm{mg} \mathrm{l}^{-1}$ of manganese, which corresponds quite well with the results from this study (Table 2) (TARIBA 2011). A high concentration of zinc in wine may cause astringent taste and haziness. The concentration recommended by OIV is up to $5 \mathrm{mg} \mathrm{l}^{-1}$. 
As in the case of grapes, organic wines had a higher potassium content. A probable explanation is mentioned in the discussion section on grapes. This result is further supported by the study of VRČEK et al. (2011). This research revealed a significantly higher concentration of $\mathrm{K}$ in organic red wines in comparison with conventional counterparts.

Differences in the As concentration between OV and IPM wine samples proved to be insignificant $(P=0.2175)$. The level of As is decreasing during winemaking, which was confirmed by numerous researchers investigating this topic (Aguilar et al. 1987, Nicolini et al. 2004, Bertoldi et al. 2013). The concentration of arsenic in both OV and IPM wines was much below the total arsenic limit of $200 \mu \mathrm{g} \mathrm{l}^{-1}$ set by International Organization of Vine and Wine.

Multivariate characterization of wine samples was performed by PCA. Factor loadings and biplot projections of observations in 2D graph of principal components are presented in Table 6 and Figure 4. The first two compo-

Table 6

Principal component analysis factor loadings of wine samples

\begin{tabular}{|c|c|c|c|}
\hline Elements & F1 & F2 & F3 \\
\hline $\mathrm{Na}$ & 0.5968 & 0.41 & 0.3376 \\
\hline $\mathrm{Mg}$ & 0.9099 & 0.1372 & 0.0126 \\
\hline $\mathrm{K}$ & -0.7764 & 0.1722 & 0.153 \\
\hline $\mathrm{Ca}$ & 0.3752 & -0.181 & -0.4268 \\
\hline $\mathrm{Mn}$ & 0.8981 & 0.0473 & 0.0292 \\
\hline $\mathrm{Al}$ & -0.0648 & 0.7137 & 0.2544 \\
\hline $\mathrm{Fe}$ & -0.0742 & 0.0854 & 0.7652 \\
\hline $\mathrm{Co}$ & 0.9838 & -0.0267 & -0.0131 \\
\hline $\mathrm{Ni}$ & 0.0934 & 0.7149 & -0.3669 \\
\hline $\mathrm{Cu}$ & -0.9685 & -0.0028 & 0.0546 \\
\hline $\mathrm{Zn}$ & 0.9556 & 0.0078 & 0.0266 \\
\hline $\mathrm{As}$ & 0.9657 & 0.0152 & 0.0239 \\
\hline $\mathrm{Ba}$ & 0.3993 & -0.559 & 0.4124 \\
\hline
\end{tabular}

nents F1 and F2 comprised $43.55 \%$ of total data variability. The elements $\mathrm{Cu}, \mathrm{Mn}, \mathrm{Zn}, \mathrm{K}$, and $\mathrm{Ni}$ showed high factor loading for principal component 1 and $\mathrm{Na}, \mathrm{Mg}$ and $\mathrm{Co}$ - for principal component 2 (Table 4, Figure 2). Individual wine samples were further projected to a $2 \mathrm{D}$ scatter plot of principal components with obvious cluster separation for OV and IPM wine samples (Figure 3). Projection of OV samples to the biplot region with a positive score for principal component F1 confirmed the strong connection of copper-based pesticide application with the residual concentration of this metal in wine. IPM wine samples were projected with the negative score of the F1 principal 


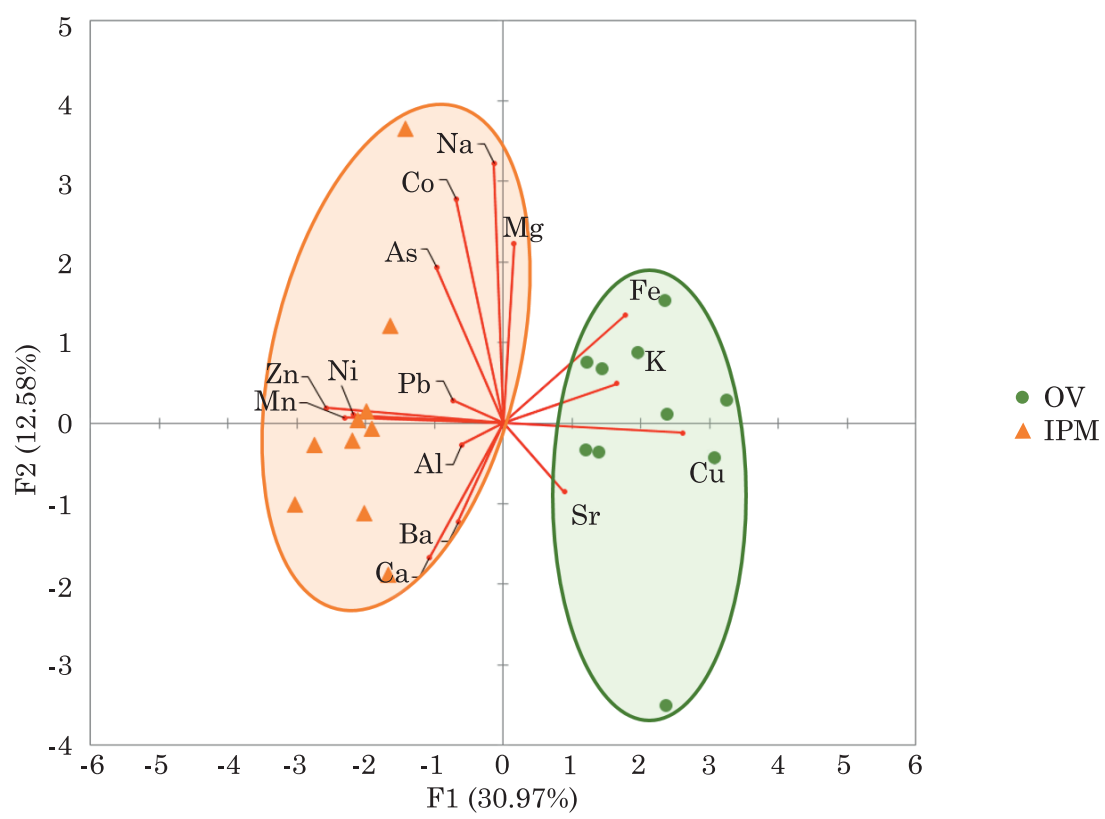

Fig. 4. PCA biplot of wine samples (ellipses are only for the visual purpose): OV - organic viticulture, IPM - integrated pest management

component with high negative factor loadings from $\mathrm{Mn}, \mathrm{Ni}$, and $\mathrm{Zn}$. This corresponds with the results of the $T$-test and it provides another proof of the probable connection between higher $\mathrm{Zn}$ and Mn concentrations in wine and the application of mancozeb-based fungicides. Nickel was a strong factor for the clustering of samples, but it was important mostly from the statistical point of view. Differences in concentrations of nickel in OV and IPM wine samples were statistically significant but small in absolute values (Table 2).

\section{CONCLUSIONS}

This study is another contribution to the issue of the impact of viticulture practice on the elemental composition of wine. However, previous studies mostly focused on the comparison of conventional and organic wines. This study fundamentally expands the knowledge about differences in the elemental composition of wines produced under the modern integrated pest management and in organic systems. The main goal of this comparison was to reveal the direct impact of viticulture in a difficult climatic season with high fungal pressure (mostly from Uncinula necator and Plasmopara viticola) when limited doses of pesticides and protective agents were used. The results showed that the elemental composition of wine and grapes was significantly influenced by the technology of pest management. Organic wine and grape 
samples contained significantly higher concentrations of copper and potassium. This difference between OV and IPM samples was attributed to the permission of a higher application dose of copper fungicides in organic viticulture. The application of $5.8 \mathrm{~kg} \mathrm{ha}^{-1}$ of $\mathrm{Cu}$ by spraying the vineyard resulted in the mean concentration $774 \pm 35 \mu \mathrm{g} \mathrm{l}^{-1}$ of $\mathrm{Cu}$ in wine. Wine from the IPM system had a concentration of $259 \pm 27 \mu \mathrm{g} \mathrm{l}^{-1}$. The higher concentration of potassium in organic wine and grapes was most likely connected with the application of protective agents containing potassium, like $\mathrm{KHCO}_{3}$ and potassium water glass. The influence of the self-protecting mechanism related to potassium metabolism against fungal pathogens when pesticide protection is insufficient cannot be overlooked either. As regards the specific composition of wine and grapes from the integrated pest management viticulture, these samples contained significantly higher concentrations of $\mathrm{Zn}$ and Mn. This difference was probably caused by the application of fungicide based on dithiocarbamate mancozeb, containing zinc and manganese in the organic form.

All these results demonstrate that elemental residues of pesticides are transferred from theplant to final wine product through the winemaking process. However, none of the investigated elements exceeded the limits set by the national, European or OIV regulations for wine. Further development of both studied viticulture systems is expected, especially in the field of pesticides. Legislation and regulations concerning copper pesticides are under constant development. The reduction of the application dose limit from $6 \mathrm{~kg} \mathrm{ha}^{-1}$ to $4 \mathrm{~kg} \mathrm{ha}^{-1}$ per year is expected, which is half the amount than in 1991 when the first European organic regulation was released. Conventional pesticides should be partially or completely replaced by biopesticides (lignocellulose biorefining) and by new methods of soil and plant care. There is also a transition to resistant PIWI varieties. It can be expected that these changes will affect the elemental composition of wines and this issue should be further studied in the future.

The results of this study may also further serve as a basis for the development of discriminatory models based on elemental analysis for distinguishing wines according to production systems.

\section{REFERENCES}

Aguilar M.V., Martinez M.C., Masoud T.A. 1987. Arsenic content in some Spanish wines influence of the wine-making technique on arsenic content in musts and wines. Z Lebensm Unters Forsch, 185(3): 185-187. https://doi.org/10.1007/BF01042044

Araya M., Olivares M., Pizzaro F. 2007. Copper in human health. Int. J. Environ. Health, 1: 608-620.

Baker B.P., Benkrook C.M., III E.G., Bennrook K.L. 2002. Pesticide residues in conventional, integrated pest management (IPM)-grown and organic foods: insights from three US data sets. Food Addit. Contam., 19(5): 427-446. https://doi.org/10.1080/02652030110113799

Bertoldi D., Villegas T.R., Larcher R., Santato A., Nicolini G. 2013. Arsenic present in the soil-vine-wine chain in vineyards situated in an old mining area in Trentino, Italy. Environ. Toxicol. Chem., 32(4): 773-779. https://doi.org/10.1002/etc.2119 
Birzele B., Meier A., Hindorf H., Krämer J., Dehne H.W. 2002. Epidemiology of fusarium infection and deoxynivalenol content in winter wheat in the Rhineland, Germany. Eur. J. Plant Pathol., 108(7): 667-673. https://doi.org/10.1023/A:1020632816441

Bolan N., Mahimairaja S., Kunhikrishnan A., Choppala G. 2013. Phosphorus-arsenic interactions in variable-charge soils in relation to arsenic mobility and bioavailability. Sci. Total Environ., 463-464: 1154-1162. https://doi.org/10.1016/j.scitotenv.2013.04.016

Bouby L., Figueiral I., Bouchette A., Rovira N., Ivorra S., Lacombe T. et al. 2013. Bioarchaeological insights into the process of domestication of grapevine (Vitis vinifera L.) during Roman Times in Southern France. PloS ONE, 8(5). https://doi.org/10.1371/journal.pone.0063195

Brandt K., Christensen L.P., Hansen-Møller J., Hansen S.L., Haraldsdottir J., Jespersen L. 2004. Health promoting compounds in vegetables and fruits. Trends Food Sci. Technol., 15(7-8): 384-393. https://doi.org/10.1016/j.tifs.2003.12.003

Coetzee P.P., Steffens F.E., Eiselen R.J., Augustyn O.P., Balcaen L., Vanhaecke F. 2005. Multi-element analysis of South African wines by ICP-MS and their classification according to geographical origin. J. Agric. Food. Chem., 53(13): 5060-5066. https://doi.org/10.1021/ /jf048268n

Vitali Č́mo D., Pelajić M., Vinković Vrček I., Krivohlavek A., Žuntar I., Karoglan M. 2018. Differences in the levels of pesticides, metals, sulphites and ochratoxin A between organically and conventionally produced wines. Food Chem, 246: 394-403. https://doi.org/10.1016/j. foodchem.2017.10.133

DARA K.S. 2019. The new integrated pest managemenent paradigm for the modern age. J. Integr. Pest Manag, 10(1): 1-9. https://doi.org/10.1093/jipm/pmz010

Fragoulis G., Trevisan M., Di Guardo A., Sorce A., van der Meer M., Weibel F., Capri E. 2009. Development of a management tool to indicate the environmental impact of organic viticulture. J. Environ. Qual., 38(2): 826-835. https://doi.org/10.2134/jeq2008.0182

García-Esparza M.A., Capri E., Pirzadeh P., Trevisan M., Gerós H. 2006. Copper content of grape and wine from Italian farms. Food Addit. Contam., 23(3): 274-280. https://doi.org/10.1080/ /02652030500429117

Kabata-Pendias A. 2010. Trace Elements in Soils and Plants (4 ${ }^{\text {th }}$ ). Boca Raton: CRC Press.

Kment P., Mihaljevič M., Ettler V., Šebek O., Strnad L., Rohlová L., Capri E. 2005. Differentiation of Czech wines using multielement composition - A comparison with vineyard soil. Food Chem, 91(1): 157-165. https://doi.org/10.1016/j.foodchem.2004.06.010

Koreñovská M., Suhaj M. 2012. Chemometric prediction of wines affiliation with organic and conventional production systems through their elemental profiles. J Food And Nutrit Res, 51(1): 23-32.

La Pera L., Dugo G., Rando R., Di Bella G., Maisano R., Salvo F. 2008. Statistical study of the influence of fungicide treatments (mancozeb, zoxamide and copper oxychloride) on heavy metal concentrations in Sicilian red wine. Food Addit, 25(3): 302-313. https://doi.org/ /10.1080/02652030701329603

Martins V., Teixeira A., Bassil E., Blumwald E., Gerós H. 2014. Metabolic changes of Vitis vinifera berries and leaves exposed to Bordeaux mixture. Plant Physiol. Biochem., 82: 270-278. https://doi.org/10.1016/j.plaphy.2014.06.016

Mengel K., Kirkby E.A., Kosegarten H., Appel T., Contam, 2001. Soil copper. Principles Plant Nutrit, 599-611.

Monaci F., Bargagli R., Focardi S. 2003. Element concentrations in Chianti Classico appellation wines. J. Trace Elem. Med. Biol., 17: 45-50.

Nardi E.P., Evangelista F.S., Tormen L., Saint'Pierre T.D., Curtius A.J., Souza S.S. de, Barbosa F. 2009. The use of inductively coupled plasma mass spectrometry (ICP-MS) for the determination of toxic and essential elements in different types of food samples. Food Chem, 112(3): 727-732. https://doi.org/10.1016/j.foodchem.2008.06.010 
Nicolini G., Larcher R., Pangrazzi P., Bontempo L. 2004. Changes in the contents of micro- and trace-elements in wine due to winemaking treatments. Vitis, 43(1): 41-45.

Онмавт C.P. 2011. View from the vineyard: a practical guide to sustainable winegrape growing. San Francisco, Wine Appreciation Guild.

PoŘízka P., DvoŘÁk M., Dvořák M., Diviš P. 2018. Elemental analysis as a tool for classification of Czech white wines with respect to grapevine varieties. J. Elem., 23(2): 709-727. https:// doi.org/10.5601/jelem.2017.22.4.1379

Shamim Uddin M., Kurosawa K. 2011. Effect of chemical nitrogen fertilizer application on the release of arsenic from sediment to groundwater in Bangladesh. Procedia Environ. Sci., 4: 294-302. https://doi.org/10.1016/j.proenv.2011.03.034

Stroh A., Bruckner P., Vollkopf U. 1994. Multielement analysis of wine samples using ICP-MS. At. Spectrosc., 15(2): 100-106.

TARIBA B. 2011. Metals in wine - Impact on wine quality and health outcomes. Biol Trace Elem Res, 144: 143-156. DOI: 10.1007/s12011-011-9052-7

Thomas T., Gunde C. 2014. Organic agriculture, sustainability and consumer preferences. organic agriculture towards sustainability. https://doi.org/10.5772/58428. Available from: https://www.intechopen.com/books/organic-agriculture-towards-sustainability/organic-agriculture-sustainability-and-consumer-preferences

VrČek I. V., Bojić M., Žuntar I., Mendaš G., Medić-Š́arić M. 2011. Phenol content, antioxidant activity and metal composition of Croatian wines deriving from organically and conventionally grown grapes. Food Chem, 124(1): 354-361. https://doi.org/10.1016/j.foodchem.2010. 05.118

Wang M., Zheng Q., Shen Q., Guo S. 2013. The critical role of potassium in plant stress response. Int. J. Mol. Sci., 14(4): 7370-7390. https://doi.org/10.3390/ijms14047370

Whitelaw-Weckert M.A., Whitelaw E.S., Rogiers S.Y., Quirk L., Clark A.C., Huang C.X. 2011. Bacterial inflorescence rot of grapevine caused by Pseudomonas syringae pv. syringae. Plant Pathol., 60(2): 325-337. https://doi.org/10.1111/j.1365-3059.2010.02377.x

Willer H., Lernoud J. 2017. The World of Organic Agriculture. Statistics and Emerging Trends 2017 (1 ${ }^{\text {st }}$ ed.). Bonn, Research Institute of Organic Agriculture (FiBL), Frick, and IFOAM Organics International. 